\title{
Early Babylonian tablets in the British Museum's Kuyunjik Collection 1: A fragment of an administrative document from Ur III Girsu?
}

\author{
Zsombor J. Földi* \\ *-Ludwig-Maximilians-Universität München. Email: zsombor.foldi@gmail.com
}

\begin{abstract}
The present paper deals with cuneiform tablets in the British Museum's Kuyunjik Collection that were in all likelihood found in Babylonia, not in Nineveh. Following a brief and preliminary overview of the corresponding material, a fragment from this group is published for the first time. It is suggested that it may belong to an administrative record from Ur III Girsu.
\end{abstract}

Keywords: British Museum, Kuyunjik Collection, collection history, Ur III period, Girsu

Cite as Földi, Zs. J. 2020: Early Babylonian tablets in the British Museum's Kuyunjik Collection 1: A fragment of an administrative document from Ur III Girsu? Hungarian Assyriological Review 1: 89-97. https://doi.org/10.52093/hara-202002-00006-000

(c) (i) $(5)$ This is an open access article distributed under the terms of the Creative Commons Attribution License, which permits unrestricted use, distribution, and reproduction in any medium, provided the original author and source are credited.

\section{Introduction}

Besides what is commonly referred to as the 'Library of Ashurbanipal', the British Museum's Kuyunjik Collection ${ }^{1}$ houses dozens of clay tablets and fragments that probably come from places other than Nineveh. ${ }^{2}$ Tablets from the simultaneous excavations of various sites in the $19^{\text {th }}$ century occasionally got confused before their shipment. Consequently, artefacts were sometimes mistakenly registered as belonging to the museum's Kuyunjik, Babylon, or Sippar Collections. ${ }^{3}$ This is best demonstrated by physical joins between tablets in the aforementioned three collections. ${ }^{4}$

The tablets in the Kuyunjik Collection for which this possibility can be reasonably considered are either later than the $7^{\text {th }}$ century BC, significantly earlier, and/or written in non-Assyrian script. ${ }^{5}$ The situation is quite obvious for royal inscriptions of Neo-Babylonian kings and Late Babylonian documents, as these were written after the fall of Nineveh in 612 BC. It is more complicated,

1 On the British excavations at Nineveh and for an overview of the collection see now Turner 2020 and George 2020 (both with earlier literature).

2 By this, the discovery (and occasionally the acquisiton) of tablets is meant. It does not apply to tablets that were written elsewhere but brought to Nineveh at the order of Ashurbanipal or one of his predecessors. On Ashurbanipal's tablet collecting practice see Fincke 2003-2004 and Frame - George 2005 (both with earlier literature).

3 'The Kouyunjik Collection seems to have become a dumping ground for tablets which the Museum staff were unable to allocate to another registered collection' (Leichty et al. 2019, 39). Compare also Walker's (apud Lambert 1992, 73-80) list of Neo-Assyrian tablets in the British Museum's Babylonian collections.

4 See, e.g., Heeßel 2005, 19; more recently Leichty et al. 2019, 706-707 as well as Hätinen 2019.

5 Numerous Nineveh tablets were written in Babylonian script (discussed in detail by Fincke 2003-2004), but it is often impossible to tell whether they were written in Nineveh or brought there from Babylonia. For the Neo-Elamite texts in the Kuyunjik Collection, Vallat (1988) suggested that they were discovered by W. K. Loftus in Malamir; it is more likely though that they were indeed unearthed in Nineveh (Reade 1992 and 2000; see also Potts 2016, 295 with further literature). 
though, for earlier tablets: Some of them might be, at least theoretically, late - and sometimes even archaising - copies of ancient texts. A few examples show that copies of early Assyrian ${ }^{6}$ and Babylonian ${ }^{7}$ rulers' inscriptions were sometimes preserved in the Nineveh libraries. Tablets of Middle Assyrian date and originally written in Aššur, most of which were probably present at the genesis of the library, are not uncommon either. ${ }^{8}$

Excluding Middle Assyrian manuscripts and the inscriptions of early rulers, there remain some thirty tablets that are considerably earlier than Neo-Assyrian, mostly dating to the Old Babylonian period (2003-1595 BC). ${ }^{9}$ Although there is a theoretical possibility that these were found in Nineveh, ${ }^{10}$ internal evidence makes it more likely that they come from Babylonian sites, excavated more or less at the same time as Nineveh.

Based on their contents, some of the aforementioned tablets can be securely assigned to Kutalla ${ }^{11}$ or Uruk, ${ }^{12}$ pointing to the excavations of W. K. Loftus at those sites as their most likely source. At least four such tablets - but probably more - likely originated in Ur and were unearthed there by J. G. (or J. E.) Taylor..$^{13}$ At least one tablet shows Late Old Babylonian features and thus presumably originated from northern Babylonia. ${ }^{14}$

The contents of some of these inscriptions have already been recognized and their text has been edited. ${ }^{15}$ The present paper deals with K.14917 which may be the earliest piece within this category and aims to be the first instalment of a series of corresponding notes and articles. ${ }^{16}$

6 See Grayson 1987, 343-344; 1991, 411-414; 1996, 257. In several of these instances, Grayson speculates whether individual manuscripts of royal inscriptions in the Kuyunjik Collection were actually found in Aššur (e.g., Grayson 1987, 139, 248, 268; 1991, 40) or Kalhu (e.g., Grayson 1991, 297-298, 327-328, 360). In the case of Ashurnasirpal II 47 (A.0.101.47) it is fairly probable that the two Nineveh manuscripts are indeed late copies of an inscription originally written on a statue of Ashurnasirpal II (see Grayson 1991, 316-317).

7 See Frame 1995, 340 and especially Bartelmus 2016, 489-532 F.3 with a bilingual inscription of Burna-Buriaš II, known exclusively from Nineveh tablets. In some instances, an Ashurbanipal colophon confirms that we are actually dealing with a Nineveh copy of the original inscription; see, e.g., Nebuchadnezzar I 5 and 8-9 in Frame's (1995) edition. A new edition of the latter two by T. Mitto (pers. comm.) is under preparation. K.7855, the only Old Babylonian royal inscription with a K number (see Frayne 1990, 834) was probably found by Loftus at Uruk; see Walker 1970, 88; Frayne 1990, 462.

8 See, e.g., Weidner 1952-1953, 204 and 208 no. 41; Lambert 1965; Reade 1986, 217-218; George 1988; Geller 1990, 211-212; Heeßel 2012, 174-182 no. 51 (refs. courtesy E. Jiménez).

9 These are conveniently listed at Leichty et al. 2019, 10. Previously, a handful of such tablets was referred to by Fincke apud Reade 2005, 369. Note that the DT, Sm, Rm and Rm-II collections, while containing mostly Neo-Assyrian material from Nineveh, also include a number of Late Babylonian tablets (see now Leichty et al. 2019, 48-52 and 194-202).

10 Note that a handful of fragments with Old Babylonian script were discovered by R. Campbell Thompson in the temple of Ištar in Nineveh; see Dalley 2001.

11 K.1377, identified by means of prosopography as a file from the archive of Șillī-Ištar of Kutalla; see Leichty et al. 2019, 39 with literature.

12 The contents of K.4709 (see n. 15) and K.7855 (see n. 7) make Uruk very likely as their place of discovery; see Leichty et al. 2019, 41.

13 In the case of K.8765 and K.13942, museographic evidence points in this direction; see Leichty et al. 2019, 42-43. K.14844 was joined by J. Politi to a tablet already associated with the city of Ur(!), see most recently Charpin 2020, 34. K.8860 (to be published in a next instalment of the present series) is a contract from Ur, as prosopography reveals. On Taylor's excavation at Ur and his findings see now Charpin 2020.

14 K.9569; see Leichty et al. 2019, 42.

15 See Leichty et al. 2019, 39-43 with the literature referred to there; for K.4709 see Michalowski Beckman 2012. K.13942 was published by Alster (1987, 201; copy by M. J. Geller), see also Alster $2005,52$.

16 The forthcoming publication of the two of them has been announced recently: K.8765 (59-10-14, 107) falls into a group that D. Charpin (2020, 26-27 §2.2 with 28 n. 78) aims to examine. K.4755+ contains 'Išbi-Erra E' and will be included into P. Michalowski's forthcoming edition of that composition (see Metcalf 2019, 67 with previous literature). 


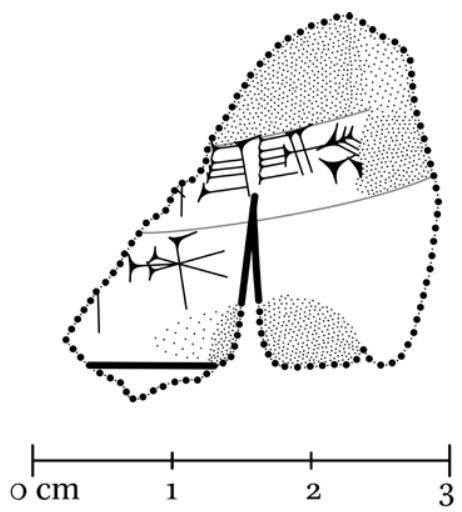

FIG. 1. Autograph of K.14917 (Zs. J. Földi).

\section{A small fragment from Ur III Girsu?}

K.14917 (Fig. 1) measures $2.6 \times 1.5 \times 1.2 \mathrm{~cm}$ and represents the lower right corner of a tablet. It was described by L. W. King in the following words:

'Bottom right-hand corner, $1 / 2$ in. by 1 in.; $2+\ldots$. lines. Part of a copy of a text, written in archaic characters, probably from a votive inscription. ${ }^{17}$

King's assumption that the fragment contained a votive inscription was based on palaeographic reasons: considering the sign forms, archaic from a Neo-Assyrian point of view, it might have been a copy of a royal or dedicatory inscription. ${ }^{18}$ Such copies are indeed known from the Kuyunjik Collection (see above), but the sign forms they use are often pseudo-archaic rather than archaic.

The fragment preserves the end of two lines with three signs and the remains of two more; these are $\mathrm{X}$ šU GI ${ }_{4}$ and $\mathrm{X}$ AN, respectively. The sequence šU GI ${ }_{4}$ points to a text in Sumerian, but it is scarcely attested in the known corpus of royal and votive inscriptions. One exception is an inscription of Gungunum, king of Larsa (1932-1906 BC), where the ruler refers to himself as šu-g $i_{4}-g i_{4}$ é-bábbar-ra 'the one who avenges the Ebabbar', ${ }^{19}$ but even this would not fit the signs' placement within the line. Otherwise, although there are different options for restoration, the word šu-g $\mathrm{i}_{4}$ 'old' is by far the most likely reading as shown by attestations in other genres. The An sign, given its numerous different readings depending on the context, does not provide a comparable clue.

17 King 1914, 141 no. 1462.

18 The absence of K.14917 at Leichty et al. 2019, 39-43 may imply that the editors of that volume shared King's view.

19 Until recently, a cone in the Schøyen Collection (CUSAS 17, 44; ed. George 2011, 96-97) was the only known manuscript of this text. On the $2^{\text {nd }}$ of June 2020, another exemplar was sold at TimeLine Auctions Ltd. in London for $£ 1,900$ (recorded in CDLI under P519796). According to the description in the auction catalogue (TimeLine Auctions 2020, 103 no. 243), it was accompanied by W. G. Lambert's and M. Ceccarelli's notes. Note thus the appearance of two manuscripts of a previously unknown inscription in a relatively short period; for its implications compare Földi 2017, 15 (with earlier literature). 
From the palaeographic point of view, the sign forms point to the late $3^{\text {rd }}$ or early $2^{\text {nd }}$ millennium $\mathrm{BC}$, unless one assumes a scribe either exceptionally talented in using archaising sign forms or copying an inscription written on stone. That both šU and $\mathrm{GI}_{4}$ were written with a row of five horizontal wedges is common in Ur III and early Old Babylonian documents but less typical in later tablets. Therefore, the sign forms make it less likely that the fragment belonged, e.g., to an Old Babylonian copy of a literary composition.

A further clue might be provided by the date of acquisition. Unfortunately, in the published record there is nothing to show when K.14917 was acquired or when it arrived at the British Museum. ${ }^{20}$ C. Bezold's catalogue of the Kuyunjik Collection contains the K tablets up to K.14230 21 and it is difficult to ascertain when the remaining fragments reached London. ${ }^{22}$ The first - and probably only - mention of K.14917 in Assyriological literature is the above description in King's catalogue in 1914. Nevertheless, there is evidence that K.14917 was registered as such in 1900 at the latest: tablets with slightly higher K numbers were included in R. Campbell Thompson's volume on lexical lists, published that year. ${ }^{23}$ Their arrangement on plates $42-44$ may imply that they were registered and autographed not long before the volume was published, but this does not reveal the date of acquisition that may be considerably earlier.

As for the possibility that the fragment belonged to an Ur III tablet, this fact virtually excludes the vast amounts of Ur III records from Puzriš-Dagān and Umma, discovered in 1908/9-1911 and makes Girsu a likely place of origin. ${ }^{24}$ What was probably the archive of the Ur III governors of Girsu was found by E. de Sarzec in 1894, but an analysis of the Girsu documents acquired from the antiquities market makes it likely that clandestine diggers plundered the site already before the official excavation. ${ }^{25}$

Considering the different genres of Ur III and Early Old Babylonian tablets at the British Museum in the last decade of the $19^{\text {th }}$ century, the administrative records from Ur III Girsu are by far the most numerous among them. The question is whether there is a text group in this category with a phraseology that could fit the preserved signs on K.14917. Besides this, also the arrangement of this information within the lines needs to be considered.

There is at least one group that fits both criteria: the so-called plough animal inspection records, also known as $\mathrm{gu}_{4}$-apin $\mathrm{gub}$-ba texts in Assyriological literature. These record the status of draught animals and were subject to a thorough analysis by W. Heimpel. Based on their contents

20 The registration of most Kuyunjik tablets took place long after their arrival at the British Museum, this is why many were already published before actually having a museum number; see Bezold 1888, 745-746 and Haupt 1890, 96-97 with 148-152 (refs. courtesy E. Jiménez). The identification of such fragments is still unfinished: for the recent identification of a long-lost fragment of Gilgameš see Jiménez 2020, 245-246.

21 Bezold 1893.

22 In King's (1914, xv) words: 'The numbers which follow them are assigned to small fragments of texts which were obtained during the earlier expeditions, but were considered at the time of their acquisition to be of too small an importance to justify their incorporation in the numbered collection of tablets. Hence, at the time the Catalogue was compiled, they remained unnumbered and were not included with the rest.'

23 Campbell Thompson 1900.

24 See Sallaberger 1999, 201-203 with Firth 2016. On the very few Ur III tablets found by Loftus and Taylor see Verderame 2008, 238; compare now Leichty et al. 2019, 10. Although there are textual references to the city of Nineveh in Ur III documents (see Goodnick Westenholz 2005, 10-11 and Zettler 2006, both with earlier literature), no such record is known to have been found in Nineveh, which makes a Nineveh origin of K.14917 unlikely.

25 Jones 1975, 43; Sallaberger 1999, 201. 
and format, Heimpel sorted them into three (A, B and C) groups. ${ }^{26}$ To judge from K.14917's preserved thickness and form (especially its curvature), it seems likely that it belonged to a small, one-column tablet rather than a large, multi-column one. This circumstance makes a text in group B the most likely as these do not have columns at all, but a group A tablet with two columns per side cannot be excluded either. ${ }^{27}$

Accordingly, the following provisional restoration of K.14917's partially preserved two lines can be suggested:

$$
\begin{aligned}
& 1^{\prime} \text {. [(š u -níg in ) x d ù]r? š u - g i }{ }_{4} \\
& \text { 2'. [g u b?-b a ?-à ]m } \\
& \text { '[(total?): n] “old” [male donk]eys(?): [asset]s(?).' }
\end{aligned}
$$

Philological notes: the traces preceding the sign šu make dùr '(young) male donkey, jackass' the most likely reading. 'Old' is a conventional translation of šu-g $\mathrm{i}_{4}$, but it hardly fits this context, as one- and two-year-old animals could also be qualified as such. Consequently, in Heimpel's words, 'it must designate a quality that is typical but not exclusive of old age'. ${ }^{28}$ In 2 ', a comparison with similar documents shows that gub-ba-à m is by far the most frequently attested in this context, whereas lá-ì-àm, libir-àm and zi-g a-àm are possible too. The translation 'assets' (lit. 'it is standing') follows Heimpel. ${ }^{29}$

To sum up, there is a certain degree of probability that K.14917 belongs to an archival document on livestock from Ur III Girsu. ${ }^{30}$ Only the eventual discovery of the missing part of the tablet can prove this hypothesis, however. Since thousands of Ur III Girsu documents in the British Museum as well as in other collections still await publication, the aforementioned tablet may very well turn up one day.

Should that happen, it will shed more light upon the acquisition history of K.14917. For the time being, it is impossible to tell how exactly it ended up among the Kuyunjik tablets. Given the absence of more Ur III documents in the Kuyunjik Collection, it is rather unlikely that the confusion took place already before the shipment of a corresponding batch of tablets to London. ${ }^{31}$ It is more probable that the fragment was found by clandestine diggers, ${ }^{32}$ acquired by the British Museum from the antiquities market after 1894 and mistakenly registered as belonging to the Kuyunjik Collection - possibly due to its size, as the latter was easily associated with tiny fragments. ${ }^{33}$

26 Heimpel 1995; see more recently Wilcke 2010.

27 On group B texts see Heimpel 1995, 80-82, for a list of documents see Heimpel 1995, 142; the latter was supplemented by Wilcke 2010, 352 with nn. 3-7.

28 Heimpel 2013, 205; 1995, 87-88; compare also Hilgert 2004, 79-80.

29 Heimpel 1995, 86; see also Wilcke 2010, 356 with n. 19.

30 The uncertainty of this solution is best demonstrated by an Old Babylonian contract from Kisurra. The last lines of RA 85, 4516 read: IGI ḩa-mu-šU!.GI / MU ma-na-bà-al-ti-/e-el! / LUGAL 'before Hammu-šībum (the PN following Anbar - Stol 1991, 27; see also Goddeeris 2009, 36); the year: "King Manna-balti-el”. As the final element of the king's name could be written with DIĜIR as well (e.g., ARM 2, 107, 9), the text, irrespective of its palaeography and other physical features, could account at least for the signs that are fully preserved of K.14917.

31 On the other hand, according to J. V. Scheil (1902, 19 with reference to Scheil 1895), the Ur III tablets from Girsu reached Mosul already in 1894 (see also Parrot 1948, 20-21; ref. courtesy L. Verderame). Therefore, it cannot be excluded that more Ur III tablets were mixed up with 'Kuyunjik' material but recognized at the British Museum as such and sorted out accordingly. Given the tiny size of K.14917, it might have escaped attention at that stage.

32 On the Ur III Girsu tablets supposedly found by H. Rassam in de Sarzez’s absence, see Verderame 2008.

33 Compare King 1914, xv. 


\section{Acknowledgements}

The author gratefully acknowledges the permission of the Trustees of the British Museum to study and publish K.14917. His research was conducted as part of his work (04.2019-05.2020) in the Electronic Babylonian Literature project, led by Enrique Jiménez (LMU München). The author is particularly grateful to Enrique Jiménez who not only suggested studying the early Babylonian tablets in the Kuyunjik Collection but also read an earlier version of this paper and provided several useful references. Further thanks go to Manuel Molina, Sarah P. Schlüter, and Lorenzo Verderame for discussing various aspects, as well as to an anonymous reviewer whose questions contributed to the argumentation. Needless to say, the author is solely responsible for any remaining mistakes.

\section{Bibliography}

Alster, B. 1987: Additional Fragments of The Instructions of Shuruppak. Aula Orientalis 5, 199-206.

Alster, B. 2005: Wisdom of Ancient Sumer. Bethesda.

Anbar, M. - Stol, M. 1991: Textes de l'époque babylonienne ancienne III. Revue d'assyriologie et d'archéologie orientale 85, 13-48.

Bartelmus, A. 2016: Fragmente einer großen Sprache. Sumerisch im Kontext der Schreiberausbildung des kassitenzeitlichen Babylonien. (Untersuchungen zur Assyriologie und Vorderasiatischen Archäologie 12) Boston - Berlin.

Bezold, C. 1888: Die Thontafelsammlungen des British Museum. Sitzungsberichte der Königlich Preussischen Akademie der Wissenschaften zu Berlin 1888, 745-763.

Bezold, C. 1893: Catalogue of the Cuneiform Tablets in the Kouyunjik Collection of the British Museum 3. London.

Campbell Thompson, R. 1900: Cuneiform Tablets from Babylonian Tablets, \&c., in the British Museum 11. London.

Charpin, D. 2020: Les découvertes épigraphiques de Taylor à Ur en 1854: Nouvelle approche. In: Charpin, D. - Béranger, M. - Fiette, B. - Jacquet, A.: Nouvelles recherches sur les archives d'Ur d'époque paléo-babylonienne. (Archibab 4 = Mémoires de N.A.B.U. 22) Paris, 13-42.

Dalley, S. M. 2001: Old Babylonian Tablets from Nineveh; and Possible Pieces of Early Gilgamesh Epic. Iraq 63, 155-167. https://doi.org/10.2307/4200507

Fincke, J. C. 2003-2004: The Babylonian Texts of Nineveh. Report on the British Museum's Ashurbanipal Library Project. Archiv für Orientforschung 50, 111-149.

FirTh, R. 2016: Some Comments on “Drehem Tablets” in the British Museum. Cuneiform Digital Library Bulletin 2016/2.

FöLDI, Zs. J. 2017: Cuneiform Tablets and the Antiquities Market: The Archives from Dūr-Abīešuh. Distant Worlds Journal 2, 7-27. https://doi.org/10.11588/dwj.2017.2.39064

Frame, G. 1995: Rulers of Babylonia. From the Second Dynasty of Isin to the End of Assyrian Domination (1157-612 BC). (The Royal Inscriptions of Mesopotamia, Babylonian Periods 2) Toronto - Buffalo - London. https://doi.org/10.3138/9781442657052

Frame, G. - George, A. R. 2005: The Royal Libraries of Nineveh: New Evidence for King Ashurbanipal's Tablet Collecting. Iraq 67, 265-284. https://doi.org/10.1017/S0021088900001388 
Frayne, D. R. 1990: Old Babylonian Period (2003-1595 BC). (The Royal Inscriptions of Mesopotamia, Early Periods 4) Toronto - Buffalo - London. https://doi.org/10.3138/9781442678033

Geller, M. J. 1990: Astronomy and Authorship. Bulletin of the School of Oriental and African Studies 53, 209-213. https://doi.org/10.1017/S0041977X00026033

George, A. R. 1988: Three Middle Assyrian Tablets in the British Museum. Iraq 50, 25-37. https:// doi.org/10.2307/4200281

George, A. R. 2011: Other Second-Millennium Royal and Commemorative Inscriptions. In: George, A. R. (ed.): Cuneiform Royal Inscriptions and Related Texts in the Schøyen Collection. (Cornell University Studies in Assyriology and Sumerology 17 = Manuscripts in the Schøyen Collection, Cuneiform Texts 6) Bethesda, 89-125.

George, A. R. 2020: Layard of Nineveh and the Tablets of Nineveh. In: Ermidoro, S. - Riva, C. (eds.): Rethinking Layard 1817-2017. Venice, 3-24.

GodDEeris, A. 2009: Tablets from Kisurra in the Collections of the British Museum. (Santag 9) Wiesbaden.

Goodnick Westenholz, J. 2005: The Old Akkadian Presence in Nineveh: Fact or Fiction. Iraq 66, 7-18. https://doi.org/10.1017/S002108890000156X

Grayson, A. K. 1987: Assyrian Rulers of the Third and Second Millennia BC (to 1115 BC). (The Royal Inscriptions of Mesopotamia, Assyrian Periods 1) Toronto - Buffalo - London.

Grayson, A. K. 1991: Assyrian Rulers of the Early First Millennium BC. I (1114-859 BC). (The Royal Inscriptions of Mesopotamia, Assyrian Periods 2) Toronto - Buffalo - London. https://doi. org/10.3138/9781442671072

Grayson, A. K. 1996: Assyrian Rulers of the Early First Millennium BC. II (858-745 BC). (The Royal Inscriptions of Mesopotamia, Assyrian Periods 3) Toronto - Buffalo - London. https://doi. org/10.3138/9781442671089

Hätinen, A. 2019: Sippar meets Kuyunjik: Join of BM 68458 and K.11550. Nouvelles Assyriologiques Brèves et Utilitaires 2019, 138-139 (No. 76).

HaupT, P. 1890: Ergebnisse einer erneuten Collation der Izdubar-Legenden. Beiträge zur Assyriologie und vergleichenden semitischen Sprachwissenschaft 1, 94-152.

HeEssel, N. P. 2005: Stein, Pflanze und Holz. Ein neuer Text zur 'medizinischen Astrologie'. Orientalia NS 74, 1-22.

HeEssel, N. P. 2012: Divinatorische Texte II. Opferschau-Omina. (Keilschrifttexte aus Assur literarischen Inhalts 5 = Wissenschaftliche Veröffentlichungen der Deutschen Orient-Gesellschaft 139) Wiesbaden.

Heimpel, W. 1995: Plow Animal Inspection Records from Ur III Girsu and Umma. Bulletin on Sumerian Agriculture 8, 71-171.

Heimpel, W. 2013: Excursus C: Āl-Šarrākī and Sesame Cultivation in Sumer. In: Owen, D. I.: Cuneiform Texts Primarily from Iri-Saĝrig / Āl-Šarrākī and the History of the Ur III Period. I: Commentary and Indexes. (Nisaba 15/1) Bethesda, 201-205.

Hilgert, M. 2004: Akkadisch sa/erku(p)pu(m) in der Ur III-Zeit - zur Landwirtschaft in Tell Išān Mizyad. In: WAETzoldt, H. (ed.): Von Sumer nach Ebla und zurück. Festschrift Giovanni Pettinato zum 27. September 1999 gewidmet von Freunden, Kollegen und Schülern. (Heidelberger Studien zum Alten Orient 9) Heidelberg, 73-92. 
JimÉNEz, E. 2020: From the Electronic Babylonian Literature Lab 10. New Fragments of Gilgameš Chiefly from the 'Babylon Collection'. Kaskal 17, 236-246.

Jones, T. B. 1975: Sumerian Administrative Documents: An Essay. In: Lieberman, S. J. (ed.): Sumerological Studies in Honor of Thorkild Jacobsen on His Seventieth Birthday, June 7, 1974. (Assyriological Studies 20) Chicago - London, 41-61.

KInG, L. W. 1914: Catalogue of the Cuneiform Tablets in the Kouyunjik Collection of the British Museum. Supplement. [London].

Lambert, W. G. 1965: A Middle Assyrian Tablet of Incantations. In: Güterbock, H. G. - Jacobsen, Tн. (eds.): Studies in Honor of Benno Landsberger on his Seventy-Fifth Birthday April 21, 1965. (Assyriological Studies 16) Chicago, 283-288.

Lambert, W. G. 1992: Catalogue of the Cuneiform Tablets in the Kouyunjik Collection of the British Museum. Third Supplement. London.

Leichty, E. V. - Finkel, I. L. - Walker, C. B. F. 2019: Catalogue of the Babylonian Tablets in the British Museum, Volumes IV-V. (Dubsar 10) Münster.

Metcalf, C. 2019: Sumerian Literary Texts in the Schøyen Collection. I: Literary Sources on Old Babylonian Religion. (Cornell University Studies in Assyriology and Sumerology 38 = Manuscripts in the Schøyen Collection, Cuneiform Texts 12) University Park.

Michalowski, P. - Beckman, G. M. 2012: The Promulgation of the Name of the Third Year of RimAnum of Uruk. In: Boiy, T. - Bretschneider, J. - Goddeeris, A. - Hameeuw, H. - Jans, G. - TavERNIER, J. (eds.): The Ancient Near East, A Life! Festschrift Karel Van Lerberghe. (Orientalia Lovaniensia Analecta 220) Leuven - Paris - Walpole, 425-433.

Parrot, A. 1948: Tello. Vingt campagnes de fouilles (1877-1933). Paris.

Pоттs, D. T. ${ }^{2} 2016$ : The Archaeology of Elam. Formation and Transformation of an Ancient Iranian State. (Cambridge World Archaeology) New York.

Reade, J. E. 1986: Archaeology and the Kuyunjik Archives. In: Veenhof, K. R. (ed.): Cuneiform Archives and Libraries. Papers read at the 30e Rencontre Assyriologique Internationale; Leiden, 4-8 July 1983. (Uitgaven van het Nederlands Historisch-Archaeologisch Instituut te Istanbul 57) Leiden, 213-222.

READE, J. E. 1992: The Elamite tablets from Nineveh. Nouvelles Assyriologiques Brèves et Utilitaires 1992, 87-88 (No. 119).

READE, J. E. 2000: Elam after the Assyrian sack of Susa in 647 BC. Nouvelles Assyriologiques Brèves et Utilitaires 2000, 89 (No. 80).

Reade, J. E. 2005: The Ishtar Temple at Nineveh. Iraq 67, 347-390. https://doi.org/10.1017/ S002108890000142X

Sallaberger, W. 1999: Ur III-Zeit. In: Attinger, P. - WÄfler, M. (eds.): Mesopotamien. Akkade-Zeit und Ur III-Zeit. (Orbis Biblicus et Orientalis 160/3) Freiburg - Göttingen, 119-390.

Scheil, J. V. 1895: Notes d'épigraphie et d'archéologie assyriennes. XI-XVII. Recueil de travaux relatifs à la philologie et à l'archéologie égyptiennes et assyriennes 17, 27-41.

Scheil, J. V. 1902: Une saison de fouilles à Sippar (Abou Habba). - [Janvier-Avril 1894]. (Mémoires publiés par les membres de l'Institut français d'archéologie orientale I/1) Le Caire.

TimeLine Auctions 2020: Antiquities \& Ancient Art. 2 June 2020. [London]. 
Turner, G. E. 2020': The British Museum's Excavations at Nineveh, 1846-1855 (ed. Russell, J. M.). (Culture and History of the Ancient Near East 115) Leiden - Boston. https:// doi.org/10.1163/9789004435377

VALlat, F. 1988: A propos de l’origine des tablettes élamites dites «de Ninive» conservées au British Muséum. Nouvelles Assyriologiques Brèves et Utilitaires 1988, $26-27$ (No. 39).

Verderame, L. 2008: Rassam's Activities at Tello (1879) and the Earliest Acquisition of Neo-Sumerian Tablets in the British Museum. In: Michalowski, P. (ed.): On the Third Dynasty of Ur. Studies in Honor of Marcel Sigrist. (The Journal of Cuneiform Studies Supplemental Series 1) Boston, 231-244.

WALKER, C. B. F. 1970: A new inscription of Sîn-kāšid. Archiv für Orientforschung 23, 88-89.

Weidner, E. F. 1952-1953: Die Bibliothek Tiglatpilesers I. Archiv für Orientforschung 16, 197-215.

WiLCKE, C. 2010: Eine Pflug-Zugtier-Inspektion aus Umma. Grenzen der Haftung für anvertrautes öffentliches Eigentum. In: Stackert, J. - Porter, B. N. - Wright, D. P. (eds.): Gazing on the Deep. Ancient Near Eastern and Other Studies in Honor of Tzvi Abusch. Bethesda, 351-372.

Zettler, R. L. 2006: Tišatal and Nineveh at the End of the $3^{\mathrm{RD}}$ Millennium BCE. In: Guinan, A. K. Ellis, M. deJ. - Ferrara, A. J. - Freedman, S. M. - Rutz, M. T. - Sassmannshausen, L. - Tinney, S. - Waters, M. W. (eds.): If a Man Builds a Joyful House. Assyriological Studies in Honor of Erle Verdun Leichty. (Cuneiform Monographs 31) Leiden - Boston, 503-514. 
奉 HAR

HUNGARIAN ASSYRIOLOGICAL REVIEW

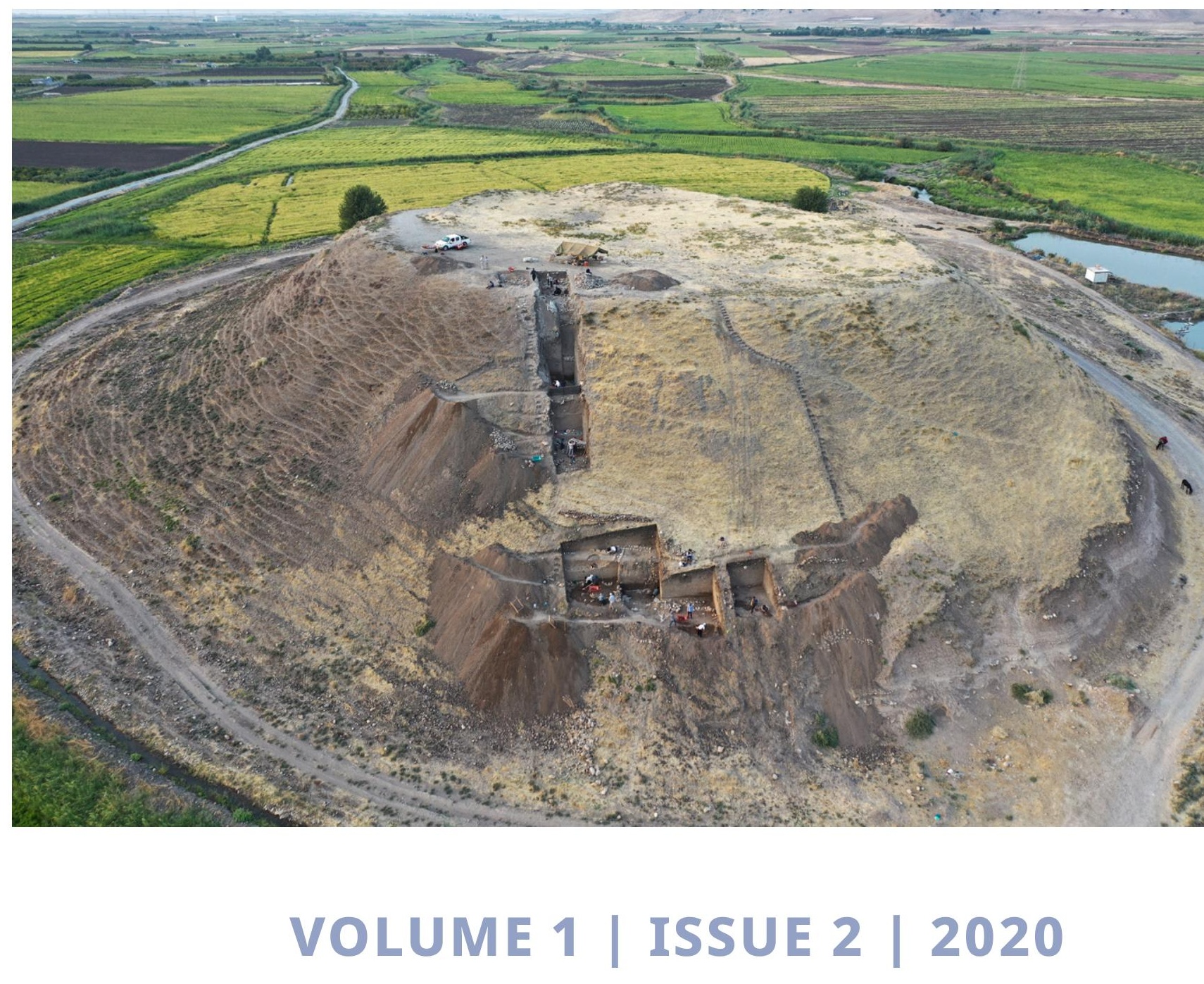





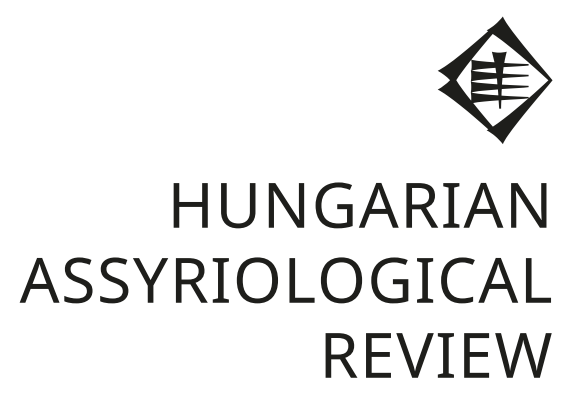


ON THE COVER:

Excavations at Grd-i Tle in 2019 -

the northern face of the tell with Trenches I and IV.

Photo: ELTE Archaeological Mission in Iraqi Kurdistan. 


\section{HUNGARIAN ASSYRIOLOGICAL REVIEW}

\section{VOLUME 1, ISSUE 2 2020}

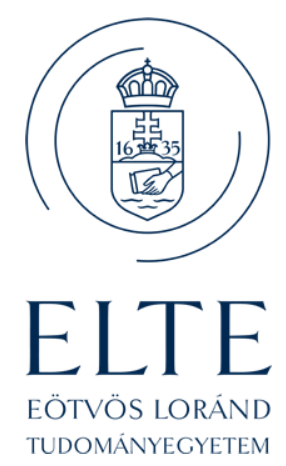

Institute of Archaeological Sciences

Institute of Ancient and Classical Studies

Eötvös Loránd University

Budapest 


\section{HUNGARIAN}

\section{HAR - Hungarian Assyriological Review}

Journal of the Institute of Archaeological Sciences and the Institute of Ancient and Classical Studies (Department of Assyriology and Hebrew Studies), Eötvös Loránd University, Budapest, Hungary.

HAR is a peer-reviewed electronic journal (HU ISSN 2732-2610) published in two issues per year. The journal covers the philology and the archaeology of the Ancient Near East, publishing research articles, brief notes, and field reports.

Papers in HAR are published under the platinum open access model, which means permanent and free access in downloadable format ( $p d f$ ) for readers and no publication fees for authors. The issues can be both downloaded for free and ordered as printed volumes at own cost.

For article submission guidelines, see https://harjournal.com/author-guidelines/

\section{Editorial board}

Editor-in-chief (szerkesztésért felelős személy):

Gábor Kalla, Eötvös Loránd University, Budapest

Associate editors:

Zsombor J. Földi, Ludwig-Maximilians-Universität, München

Zsolt Simon, Ludwig-Maximilians-Universität, München

\section{Editorial board:}

Tamás Dezső, Eötvös Loránd University, Budapest

Gábor Zólyomi, Eötvös Loránd University, Budapest

Technical editor:

Attila Király

Publisher (kiadó és kiadásért felelős személy):

Gábor Kalla, Eötvös Loránd University, Budapest

Registered office (a kiadó székhelye):

Institute of Archaeological Sciences, Múzeum krt. 4/B., 1088 Budapest, Hungary

\section{Email address:}

info@harjournal.com

\section{Design and typesetting:}

Attila Király (attila@litikum.hu)

using Noto font family by Google Inc., under the terms of the SIL Open Font License. 


\section{CONTENTS}

\section{Hungarian Assyriological Review}

\section{volume 1, issue 2,2020}

Early Babylonian tablets in the British Museum's Kuyunjik Collection 1:

A fragment of an administrative document from Ur III Girsu?

Zsombor J. Földi

The morphophonological analysis of Hittite šipantaš, šipandaš '(s)he libated'

Alwin Kloekhorst

A fresh look at recently published Anatolian hieroglyphic seals

Massimo Poetto

Floh im Ohr: Forrers Ahhijawā-Deutung, Āhhijā und ihr kilikischer Nachzügler Hijawa

Diether Schürr

\section{Hungarian Excavations at Grd-i Tle}

The geomorphological and environmental context of the Grd-i Tle archaeological site István Viczián

Hungarian Assyriological Review author guidelines 